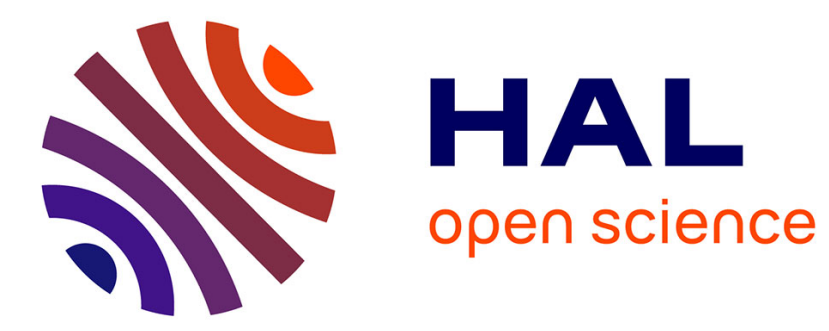

\title{
Modelling of a VSC-Based Multi-Terminal HVDC Network for Dynamic Stability Analysis
}

\author{
K. Shinoda, A Benchaib, X. Guillaud, S. Bacha, Bruno François
}

\section{To cite this version:}

K. Shinoda, A Benchaib, X. Guillaud, S. Bacha, Bruno François. Modelling of a VSC-Based MultiTerminal HVDC Network for Dynamic Stability Analysis. COMPEL: The International Journal for Computation and Mathematics in Electrical and Electronic Engineering, 2017. hal-01918167

\section{HAL Id: hal-01918167 https://hal.science/hal-01918167}

Submitted on 9 Nov 2018

HAL is a multi-disciplinary open access archive for the deposit and dissemination of scientific research documents, whether they are published or not. The documents may come from teaching and research institutions in France or abroad, or from public or private research centers.
L'archive ouverte pluridisciplinaire HAL, est destinée au dépôt et à la diffusion de documents scientifiques de niveau recherche, publiés ou non, émanant des établissements d'enseignement et de recherche français ou étrangers, des laboratoires publics ou privés. 
COMPEL - The international journal for computation and mathematics in electrical and electronic engineering, Vol. 36 Iss: 1, pp.240 - 257, 2017

\section{Modelling of a VSC-Based Multi-Terminal HVDC Network for Dynamic Stability Analysis K. Shinoda, A. Benchaib, X. Guillaud, S. Bacha, B. Francois}

Abstract-

- Purpose

Self-commuted Voltage Source Converter (VSC) can significantly extend the flexibility and operability of HVDC system and be used to implement the concept of Multi-Terminal HVDC (MTDC) grid. In order to take full advantage of MTDC systems, its overall behavior must be characterized in quasi static and dynamic states. Based on the numerous literatures, a dedicated 2-level VSC model and its local controllers as well as DC grid voltage regulators are developed for this purpose. Furthermore, the requirement of the system to guarantee all the physical constrains must be well-assessed and concrete demonstrations must be provided by numerical simulations.

- Design/methodology/approach

Firstly, a 2-level VSC model and its local controllers as well as DC grid voltage regulators are developed. Then, various DC cable models are investigated and their characteristics are assessed in the frequency domain. Those developed models are combined to form a 3-Terminal HVDC grid system on Matlab/Simulink platform. To analyse the stability of this electrical system, the dynamics of the system against variations of power dispatch are observed.

- $\quad$ Findings

To analyse the stability of this electrical system, the dynamics of the system against variations of power dispatch are observed. The differences in the DC grid voltage dynamics and the power flow of the converter stations coming from the embedded primary controls are analysed and the technical requirements for both cases are assessed.

- Originality/value

In this paper, the dynamic stability of a MTDC system has been analysed and assessed through an adequate simulation model including its control scheme and the cable models. The interests of the improved PI model for cables are highlighted.

A short version of this paper has been presented at CISTEM 2014 Conference.

Keywords-component: HVDC grid, Voltage source converter (VSC), MTDC Grid, DC Cable, Primary Control, Voltage droop control, Wind power generation.

\section{INTRODUCTION}

Over the last decade, integration of renewable energies has been a serious challenge around the world due to the sustainable development concerns (Davigny at al. 2014). In Europe, EU countries have agreed an ambitious development plan of renewable energy integration which targets 27 [\%] share of final energy consumption by 2030 towards the complete $\mathrm{CO}_{2}$ abatement by 2050 (European Commission 2014). Wind energy is considered as a keystone in the policy of European countries to reach those targets (Z.Q. Zhu, Jiabing $\mathrm{Hu} 2013$ ). Due to the lack of remaining onshore sites, offshore wind farms are prospected to rapidly increase its share in the next decades (Bell et al. 2010). Many of large offshore wind farm projects have been already launched and started their commercial operations (Barnes and Beddard 2012). However, offshore wind farms are mostly located far away from the electric coupling point of the national grid, and so a largescale power transfer implies a large amount of reactive power from submarine cables in HVAC. Hence, HVDC technology appears as a better economic solution (Asplund, G. et al. 2013) (Ackermann and Negra 2005) (Schifreen and Marble 1956).

HVDC technology has been led by remarkable advances in power electronic devices. Voltage Source Converter (VSC) is capable of bi-directional power flow and can significantly extend the flexibility and operability of the HVDC technology, compared to conventional Line-Commuted Converter (LCC) based HVDC. The radial or meshed connection of HVDC configuration, so-called Multi-Terminal Direct Current (MTDC) grid, has become an attractive solution to acquire further reliability and flexibility to achieve the EU's renewable energy integration target, and moreover, to enhance energy security and economic efficiency of electric power network. This concept is also known as "SuperGrid" (Asplund, G. et al. 2013).

In order to take full advantage of MTDC systems, its overall behavior must be characterized in quasi static and dynamic states. Furthermore, the requirement of the system to guarantee all physical constrains must be well-assessed, and concrete demonstrations must be provided by numerical simulations.

Main contributions of this paper are:

- The development of appropriate MTDC network simulation models including power electronic controllers,

- The analysis on power transfer capability of the grid connected converter,

- The stability analysis of MTDC network in quasi static and dynamic states (Broutin D. and Francois B. 2000),

- The assessment of required dynamic response of embedded controllers.

To perform a stability analysis, a compromise must be chosen between the simplification of used models and the required accuracy. In this paper, the followed method is to design linear models of each device. This method enables an acceptable computation time while taking into account 
COMPEL - The international journal for computation and mathematics in electrical and electronic engineering, Vol. 36 Iss: 1, pp. $240-257,2017$

behavior of all equipment and also effects of the control system

Firstly, a 2-level VSC model and its modulation/regulation controls are recalled. Then, various DC cable models are investigated, and their behaviors are checked in the frequency domain. To get a more accurate model, an improved PI model, is developed and based on the chain connection of PI lumped parameterized cells. Those developed models are combined to form a MTDC grid system. Several DC grid voltage controllers are developed, and transmission capability is quantified according to the dc voltage variations. Then, achievable performances in dynamic stability are analyzed.

\section{TEST SYSTEM CONFIGURATION}

VSCs are intensively used to perform required power electrical conversions under the intermittency of renewable resources and also under prescribed technical constrains from the main AC transmission system. In case of fault, the balancing between the generated power and exported power is timely broken. Primary DC voltage controllers are needed in practice to damp DC voltage oscillations into security margins within a certain time. To study and understand the behavior of these power systems in quasi static and dynamic states, a HVDC grid topology has been considered. The proposed HVDC grid model consists of two onshore terminals (VSC 1 and VSC2) and one offshore terminal (VSC3) (Fig. 1). All 1000 MW VSC stations are associated with $75 \mu \mathrm{F}$ DC capacitors and connected through $100[\mathrm{~km}]$ cables.

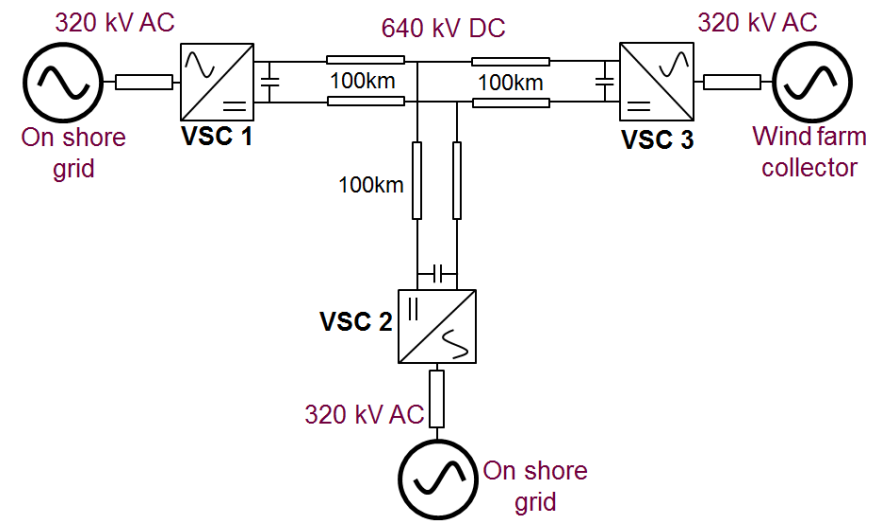

Fig. 1. Architecture of the studied 3 terminal HVDC system

\section{VSC CONTROL SYSTEM}

\section{A. Introduction of VSC and Modelling Method}

VSC transmission can offer several advantages in addition to LCC (Andersen et al. 2005) (Jones and Davidson 2013):

- Independent control of active and reactive power within the rating of the equipment,

- Bi-directional power flow control,

- Reduction of the harmonics content by fast switching,

- Requirement of smaller filters.

Disadvantages of 2-levels VSC are the slightly higher power losses and the smaller power rating.

VSC consists of several Insulated Gate Bipolar Transistors,
IGBT, which allows switching on and off large currents by controlling the gate signals (Fig. 2). As high frequency switching is possible, the filtering of harmonic components is easily performed by chokes, and so that nearly ideal AC current outputs $\left(i_{s_{a}}, i_{s_{b}}, i_{s_{c}}\right)$ are obtained. Then an average model of the power converter can be considered for the control design of power conversion between $\mathrm{DC}$ and $\mathrm{AC}$ grid.

\section{Offshore DC Grid}

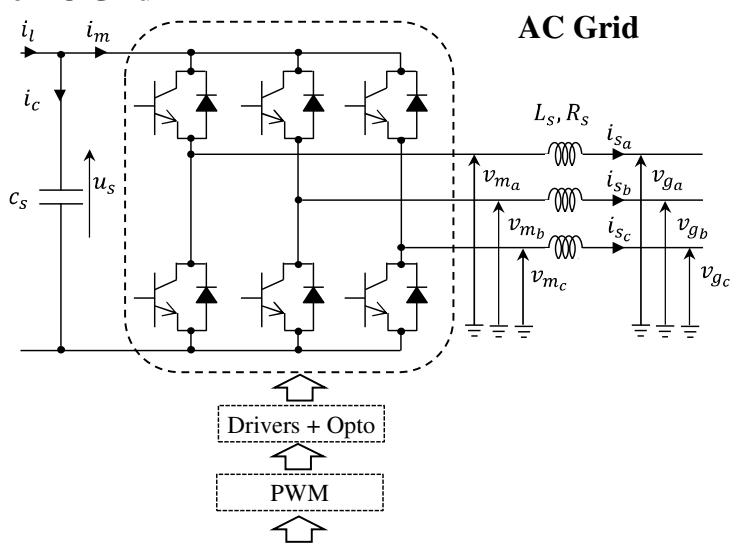

Fig. 2. Structure of a 2-Level VSC

\section{B. Principle of VSC Control}

A Phase Lock Loop (PLL) is used to track the AC grid voltage frequency and phase angle. A synchronised rotating $d q$ frame with $\mathrm{AC}$ voltages is considered for the modelling and control design (Haileselassie et al. 2008), (Lee et al. 2011). Then direct and quadrature coordinates of electrical quantities are calculated with the Park transform.

The designed control system is divided into two main parts: the inner control and the outer control (Fig. 3) (Rault 2014). The role of inner control is to control the currents $i_{s_{d}}$ and $i_{s_{q}}$ by regulating $d$ and $q$ coordinates of modulated voltages $\left(v_{m_{d}}^{*}\right.$ and $\left.v_{m_{q}}^{*}\right)$ in the Park frame. The outer control generates:

- The $d$-axis current reference, which can be either given by the active power controller or the DC voltage controller

- The $q$-axis current reference can be either given by the reactive power controller or the $\mathrm{AC}$ voltage controller

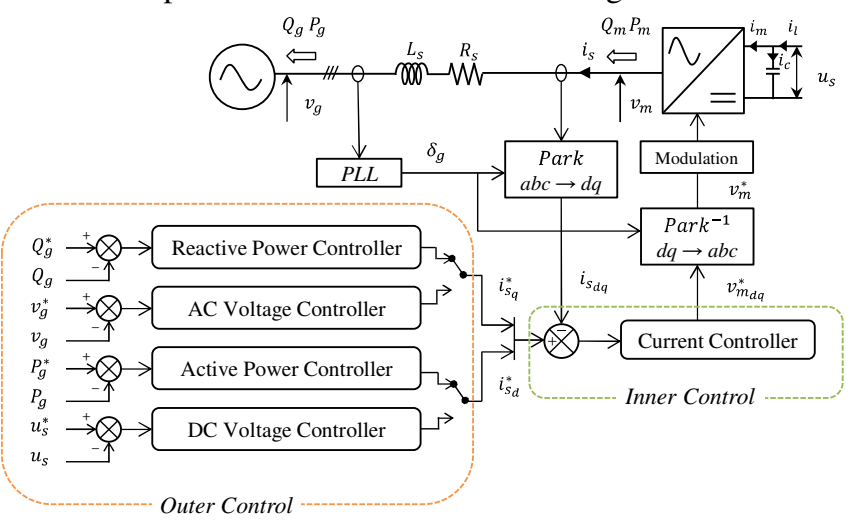

Fig. 3. Structure of the 2 Level Control System in a $d q$ rotating frame 
COMPEL - The international journal for computation and mathematics in electrical and electronic engineering, Vol. 36 Iss: 1, pp. $240-257,2017$

\section{Design of the Current Controller}

In a $d q$ rotating frame, $\mathrm{AC}$ currents are expressed by following dynamic equations with $d$ and $q$ coordinates of grid voltages $\left(v_{g_{d}}\right.$ and $\left.v_{g_{q}}\right)$ and modulated voltages $\left(v_{m_{d}}\right.$ and $\left.v_{m_{q}}\right)$ :

$$
\begin{aligned}
& \frac{d i_{s_{d}}}{d t}=\frac{1}{L_{s}}\left(v_{m_{d}}-v_{g_{d}}-R_{s} i_{s_{d}}+\omega L_{s} i_{s_{q}}\right) \\
& \frac{d i_{s_{q}}}{d t}=\frac{1}{L_{s}}\left(v_{m_{q}}-v_{g_{q}}-R_{s} i_{s_{q}}-\omega L_{s} i_{s_{d}}\right) .
\end{aligned}
$$

As coupled terms appear, the current controller includes a decoupling action, and a $P I$ or $I P$ controller is used to avoid the residual steady state error between the reference and the output current (Fig. 4).

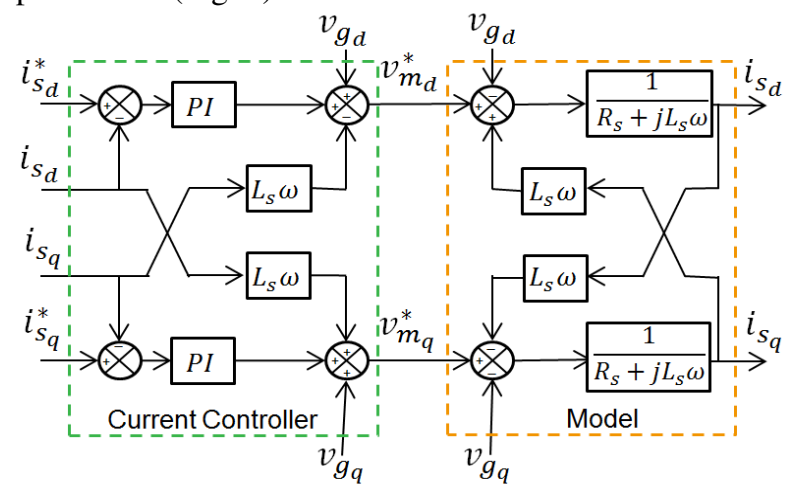

Fig. 4. Current Controller in a $d q$ frame

Parameters of the corrector affect the response time and stabilization characteristics of the overall system. Therefore, they must be determined carefully (Robyns, B. et al. 2002).

\section{Active and Reactive Power Controller}

As long as the $d q$ frame is aligned with the $d$ component of the grid voltage, the quadrature component of the voltage is equal to zero. Hence, the active and reactive grid powers are simply obtained by following expressions:

$$
\begin{gathered}
p_{g}=v_{g_{d}} i_{s_{d}}+v_{g_{q}} i_{s_{q}}=v_{g_{d}} i_{s_{d}} \\
q_{g}=-v_{g_{d}} i_{s_{q}}+v_{g_{q}} i_{s_{d}}=-v_{g_{d}} i_{s_{q}}
\end{gathered}
$$

Then any active and reactive power references can be easily converted into the current references (Haileselassie, T.M. et al. 2008):

$$
\begin{aligned}
& i_{s_{d}}^{*}=\frac{p_{g}^{*}}{v_{g_{d}}} \\
& i_{s_{q}}^{*}=-\frac{q_{g}^{*}}{v_{g_{d}}}
\end{aligned}
$$

\section{E. DC Voltage Controller}

As the DC voltage is issued from a capacitor, it is modelled by the following linear differential equation:

$$
\frac{d u_{s}}{d t}=\frac{1}{C_{s}}\left(i_{l}-i_{m}\right) .
$$

By considering the input current $\left(i_{l}\right)$ as a disturbance, the voltage can be regulated by decreasing the error between the reference. The measured DC voltage with a $P I$ or $I P$ controller, which sets the required capacitor current $\left(i_{m}^{*}\right)$ (Fig.5):

$$
i_{m}^{*}=\left(K_{p}+\frac{K_{i}}{s}\right)\left(u_{s}^{*}-u_{s}\right)
$$

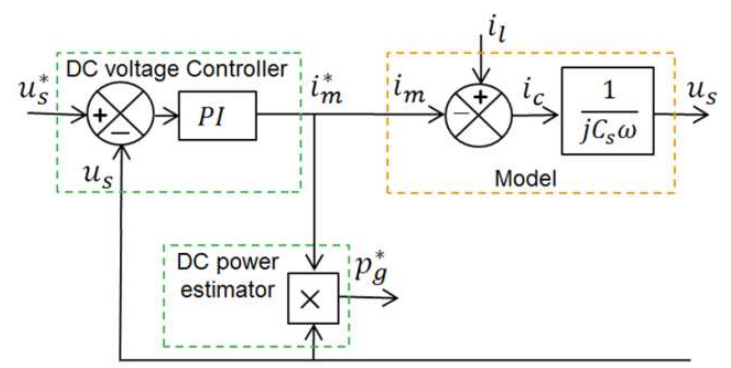

Fig. 5. DC Voltage Controller

If losses are small in the power electronic converter, then the balancing of powers shows that the full DC power is converted to the active power in the AC side (fig. 2):

$$
i_{m} \cdot u_{s}=p_{g}
$$

Then, the corresponding power reference is deduced by assuming that the input DC current $\left(i_{l}\right)$ is a disturbance and corrected by the $P I$ controller.

$$
p_{g}^{*}=i_{m}^{*} \cdot u_{s}
$$

According to this scheme, the DC voltage can be controlled by the current injection and extraction with the AC grid (equ 5).

\section{HVDC CABLE}

To obtain the accurate dynamics of the MVDC system, the dynamics of cable has to be considered, and now various models of cables are examined.

\section{A. Wide Band Cable Modelling}

The transmission line or cable systems can be characterized by two main matrices of the characteristic admittance matrix and the propagation function (Broutin D. and Francois B. 2000). Wide Band model is the most sophisticated model available and is used for a wide range of frequency for both overhead lines and underground cables. WB model is formulated in the phase domain taking into account the full-frequency-dependence of the line parameter. A Wide Band cable model is developed by using the cable parameters studied for the INELFE link project (Descloux 2013). The required information of the cable arrangement and the fundamental parameters, such as the radius, the resistivity of the core and the screen, the permittivity of the insulator, are detailed in Table 1 and Table 2. Then the admittance and impedance matrices are fitted into the cable for each frequency by the vector fitting tool (Kocar et al. 2008).

\begin{tabular}{|c|c|c|}
\hline \multicolumn{2}{|c|}{ Table 1. Arrangement of the Cable } \\
$\begin{array}{c}\text { Vertical } \\
\text { Distance [m] }\end{array}$ & $\begin{array}{c}\text { Horizontal } \\
\text { Distance [m] }\end{array}$ & $\begin{array}{c}\text { Outer Insulation } \\
\text { Radius [m] }\end{array}$ \\
\hline 1.33 & 0 & $63.8 \mathrm{e}-3$ \\
\hline
\end{tabular}


COMPEL - The international journal for computation and mathematics in electrical and electronic engineering, Vol. 36 Iss: 1, pp. $240-257,2017$

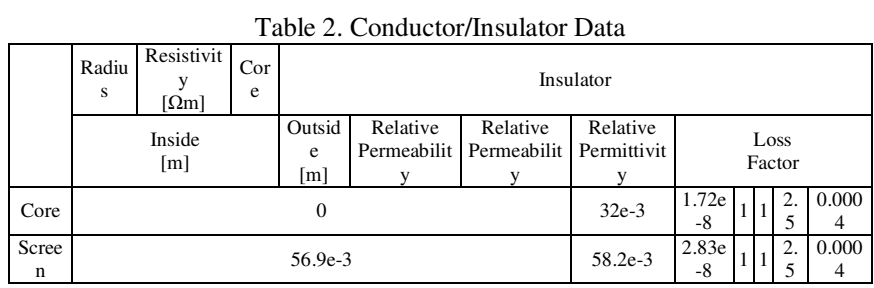

Table 3. Impedance Matrix at $10 \mu \mathrm{Hz}$

\begin{tabular}{|c|c|c|c|}
\hline \multirow{4}{*}{ Impedance } & \multicolumn{3}{|c|}{ Matrix } \\
\hline \multirow{2}{*}{$\begin{array}{c}\text { Series } \\
\text { Resistance }\end{array}$} & & 1 & 2 \\
\cline { 2 - 4 }$[\Omega / \mathrm{km}]$ & 1 & $5.35 \mathrm{e}-3$ & $9.87 \mathrm{e}-9$ \\
\cline { 2 - 4 } & 2 & $9.87 \mathrm{e}-9$ & $6.02 \mathrm{e}-2$ \\
\hline \multirow{4}{*}{$\begin{array}{c}\text { Series } \\
\text { Inductance } \\
\mathrm{L}[\mathrm{mH} / \mathrm{km}]\end{array}$} & 1 & $3.65 \mathrm{e} 0$ & 2 \\
\cline { 2 - 4 } & 2 & $3.48 \mathrm{e} 0$ & $3.48 \mathrm{e} 0$ \\
\hline \multirow{4}{*}{$\begin{array}{c}\text { Shunt } \\
\text { Conductance } \\
\mathrm{G}[\mathrm{S} / \mathrm{km}]\end{array}$} & 1 & $6.07 \mathrm{e}-8$ & $-6.07 \mathrm{e}-8$ \\
\cline { 2 - 4 } & 2 & $-6.07 \mathrm{e}-8$ & $4.41 \mathrm{e}-7$ \\
\hline \multirow{2}{*}{$\begin{array}{c}\text { Shunt } \\
\text { Capacitance } \\
\mathrm{C}[\mu \mathrm{F} / \mathrm{km}]\end{array}$} & 1 & $2.42 \mathrm{e}-1$ & $-2.42 \mathrm{e}-1$ \\
\cline { 2 - 4 } & 2 & $-2.42 \mathrm{e}-1$ & $1.76 \mathrm{e} 0$ \\
\hline
\end{tabular}

\section{B. Frequency Analysis of Simple PI Electrical Circuit Model}

The impedance matrix at $10[\mu \mathrm{Hz}]$, which is derived in the process of the Wide Band cable modelling, is chosen as a reference value to be fitted on a PI electrical circuit model. The obtained impedance matrix at $10[\mu \mathrm{Hz}]$ is shown in Table 3 . Then frequency analyses are carried out, and results are compared with that of Wide Band Model calculated with EMTP-RV software.

The obtained impedance matrix at $10[\mu \mathrm{Hz}]$ is multiplied by 100 to simulate $100[\mathrm{~km}]$ cable connection, and then assigned to the PI model (shown in Fig. 6).

To fit it in PI model, only the parameters of core conductor and core to ground are taken into account. To get a more accurate model, the chain connection of ten PI lumped parameterized cells (representing $10 \mathrm{~km}$ cable) is considered to have a $100[\mathrm{~km}]$ line model.

In Fig. 7, the obtained impedance and phase shift of the $P I$ models for various frequencies are compared with that of Wide Band model. It can be seen that the simple PI model does not represent the actual behavior of the cable, and so the PI model must be improved.

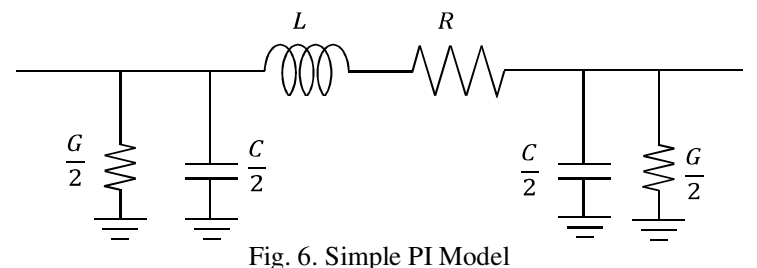

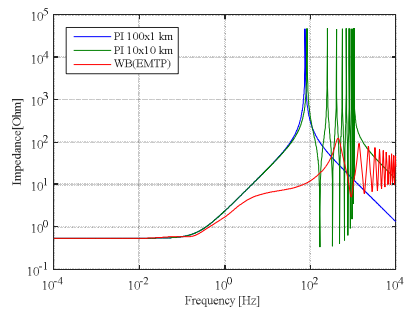

a)

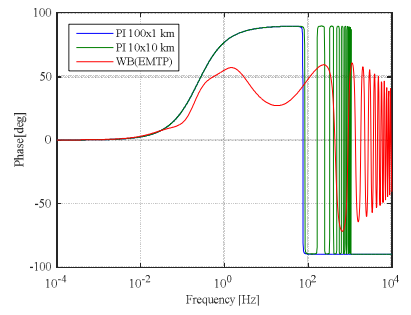

b) Phase
Fig. 7. Comparison of Bode Plots of the simple PI and WB model

\section{Improved PI Model}

The existence of coupling inductance on a simple PI model can have a large impact on the accuracy of the cable behaviour. An improved PI model is proposed by P. Rault (Rault 2014). This model takes into account the mutual inductance between the core and the screen conductor of the cable, as shown in Fig. 8.

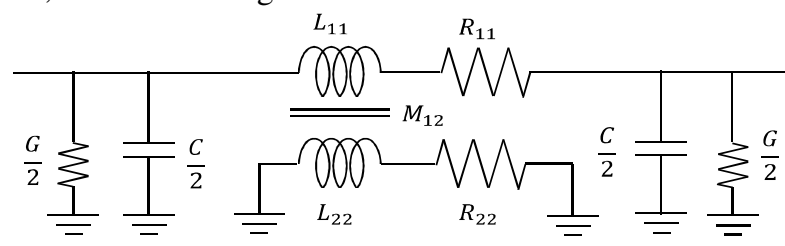

Fig. 8. Improved PI Model

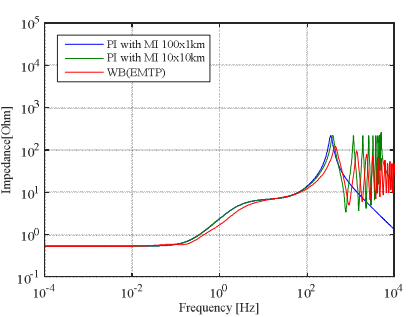

a)

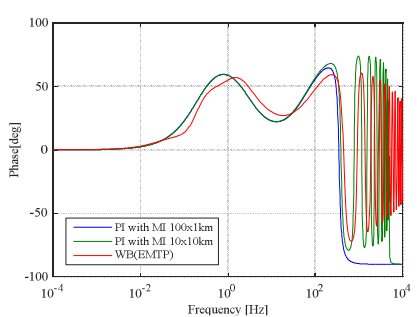

b) Phase
Fig. 9. Bode Plots between Improved PI and WB model

The value of the mutual inductance is obtained from the Wide Band model fitting. The ten PI cells based model is also developed.

As it is observed in Fig. 9, the improved PI model has a better accuracy than the simple PI model. In contrast to the behavior of the simple PI model, the improved PI model has the first line mode at the nearly same frequency as the Wide Band model. Moreover the improved PI model with ten PI cells has several frequency modes which are the same as the behavior of the Wide Band model.

\section{Frequency Analysis of Multi Cable Connection}

To consider practical conditions, multi-phase cable models are developed. Similarly to the previous section, a multi-phase 
COMPEL - The international journal for computation and mathematics in electrical and electronic engineering, Vol. 36 Iss: 1, pp. $240-257,2017$

Wide Band cable model is developed on EMTP-RV. Then calculated impedance matrix is applied to the improved $P I$ models, and the results of the frequency analysis are compared. To develop multi-phase cable model, the geometrical arrangements of the cables are modified to 1.33 [m] vertical distance, $0.5[\mathrm{~m}]$ horizontal distance. The other parameters such as the outer insulation radius and the dielectric properties remain unchanged. The same values for the conductor/insulator data (as in previous subsection) are used. The cable models are connected by a $50[\mu \mathrm{F}]$ capacitor, which is adequate as a station capacitance.

As it is observed in Fig. 10, the frequency scan responses of the improved PI models are very close to those of the Wide Band model. The ten cell based model has the first 10 line modes at almost the same frequency of the Wide Band model. Thus, the proposed cable models are validated.

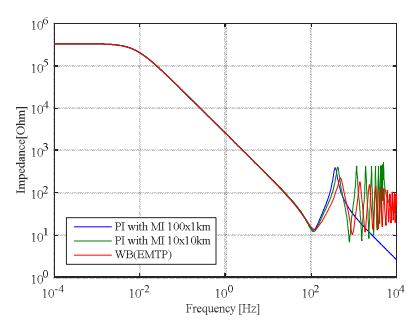

a) Impedance

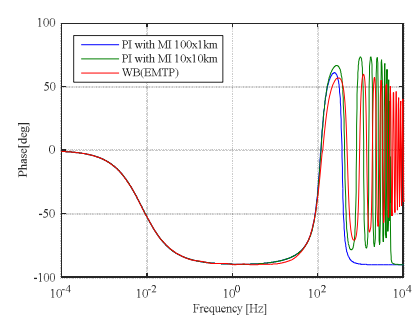

b) Phase
Fig.10. Comparison of Bode Plots in Multi Cable Connection

\section{PRIMARY VOLTAGE CONTROL OF MTDC SYSTEM}

\section{A. Primary Control Methods}

Due to impedances (coming from cables), voltage drops appear between power stations. The DC grid voltage control is the most important role for the VSC stations to accomplish the secure operation of a MTDC system. The DC grid voltage has to be maintained in a certain range against any power variations; otherwise a large DC voltage drop can temporarily limit the capability of the AC voltage controller and affect the linear stability of the control systems (Zhang et al. 2011). For this matter, several strategies, often called Primary Control Methods, exist. The primary control must guarantee the power balance in the MTDC grid. Many primary control methods, such as Voltage Margin Method (Nakajima and Irokawa 1999), Ratio Control (Bazargan et al. 2009), etc., have been proposed in past decades (Pinto et al. 2011), (GonzalezLongatt et al. 2013) and (Bacha et al. 2014). However, most of them are based on two main methods called Master Slave Method and Voltage Droop Method or a combination of both of them (Wang and Barnes 2014).

\section{B. Master Slave Method}

Master Slave Method is an extension of the method adapted for the control of a point to point HVDC system (Barker and Whitehouse 2010). Only one station in the MTDC system, which is called "Master" station, controls the DC grid voltage to keep it in a certain range while other stations, which are called "Slave" stations (Fig. 11). "Slave" stations control their power injection or absorption to/from the DC grid. All power variances in the DC grid are compensated by the Master station and balanced. Thus, the Master Station must be connected with a strong AC grid, which must keep continuously large power reserves.

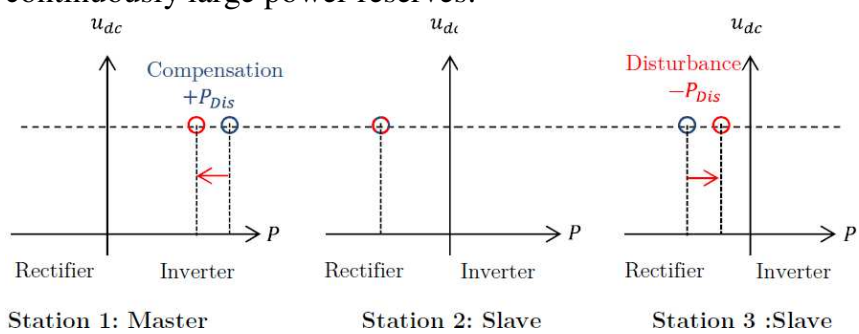

Fig. 11. Concept of the Master Slave method

\section{Voltage Droop Method}

In contrast to the Master Slave Method, several power stations can contribute to the voltage regulation with the Voltage Droop Method. Classically, the power contribution $\left(\Delta P_{g}\right)$ of these stations is linearly deduced from the voltage deviation $\left(\Delta u_{s}\right)$ as (Fig. 12):

$$
\Delta P_{g}=\frac{1}{k} \Delta u_{s}
$$

The droop value of the stations can largely affect the dynamic response of the system. Hence, the droop values of each station must be carefully chosen. Since the DC grid balance is achieved by several stations, this method is more reliable and suitable for multi-terminal HVDC system (Akkari et al. 2015).

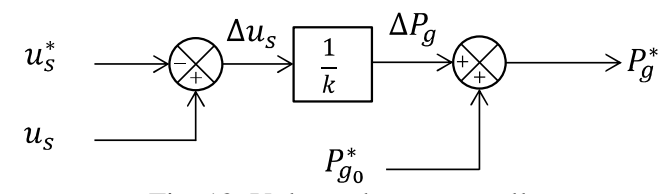

Fig. 12. Voltage droop controller

The main drawback of this method is the linear behavior of the controller. Hence the DC grid voltage is not strictly constant (Fig. 13) (Dragon et al. 2014).

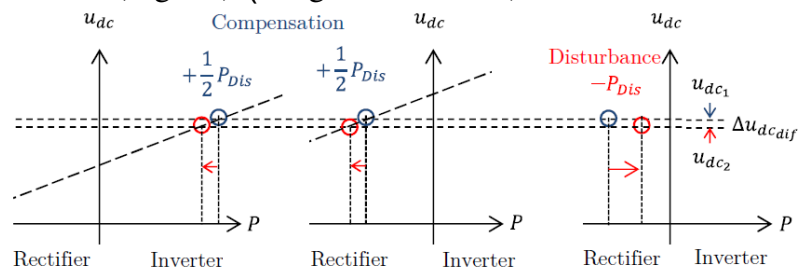

Station 1: Droop Station 2: Droop Station 3 : Power Control

Fig. 13. Concept of the Voltage droop controller

\section{ANALYSIS ON THE POWER TRANSMISSION CAPABILITY} OF VSC

\section{A. Mathematical description}

To achieve a practical operation of the MTDC grid, each 
COMPEL - The international journal for computation and mathematics in electrical and electronic engineering,

Vol. 36 Iss: 1, pp. $240-257,2017$

converter must be properly sized to be capable to transfer a certain power. By neglecting the filter resistance $R_{S}$ (in Fig. 2), the power flow between the converter and the $\mathrm{AC}$ grid is expressed by the vector diagram (Fig.14).

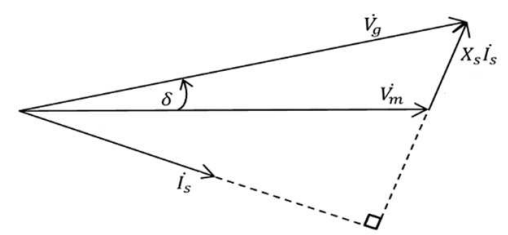

Fig. 14. Vector diagram of the grid connection

The vector $\dot{V}_{m}$ corresponds to the AC side voltage of the converter. When a constant switching frequency and the Space Vector Modulation technique are used, the rms value of the voltage output $V_{m}$ is expressed by using the conversion ratio $m$ $(0<m \leq 1)$ and the DC grid voltage $u_{s}$ (Bouhali et al. 2009):

$$
V_{m}=\frac{u_{\mathrm{s}}}{\sqrt{6}} m \text {. }
$$

As it is seen, the AC voltage output of the converter is limited by the DC grid voltage. Considering the maximum conversion ratio $(m=1)$, the maximum AC voltage is given as:

$$
V_{m_{\text {Max }}}=\frac{u_{\mathrm{s}}}{\sqrt{6}} .
$$

The active and reactive powers fed to the AC grid are given as follows:

$$
\begin{gathered}
P_{g}=3 \frac{V_{g} V_{m} \sin \delta}{X_{s}} \\
Q_{g}=3 \frac{V_{g} V_{m} \cos \delta-V_{g}^{2}}{X_{s}}
\end{gathered}
$$

with $X_{s}=\omega L_{s}$.

Combining both equations, a circle equation is obtained:

$$
P_{g}{ }^{2}+\left(Q_{g}+Q_{0}\right)^{2} \leq\left(3 \frac{V_{g} V_{m}}{X_{s}}\right)^{2}
$$

with

$$
Q_{0}=\frac{3 V_{g}^{2}}{X_{S}}
$$

From (14), the maximum active power $P_{g_{M a x}}$ is obtained with the reactive power $Q_{g}=-Q_{0}$ and the modulation index at maximum value $(m=1)$ :

$$
P_{g_{\text {Max }}}=3 \frac{V_{g}}{X_{s}} \frac{u_{\mathrm{s}}}{\sqrt{6}}
$$

When disturbance such as a power variation at one of the stations or sudden loss of a power station occurs, the DC grid voltage starts to decrease or increase until the disturbance is compensated by the appropriate actions taken by the other power stations. If there are some operational constrains related to the variation of the DC voltage, those can interfere with the actions to bring back the DC grid voltage to a steady state and cause instability of the system. However, the control of VSC is often designed in a $d q$ rotating frame. To maintain the operating point within an admissible region which satisfies all the operational constrains, those constrains have to be interpreted in a comprehensive manner for the controllers. Hence, the possible operational constrains of the 2-level VSC are investigated and analyzed in the $d q$ frame, then the impacts of the DC grid voltage variation on those constrains are analyzed.

\section{B. Admissible AC Current}

The admissible AC current fed by the power electronic converter is restricted by the thermal capability of the grid components such as the AC grid cables and the phase reactor. For a given AC grid voltage $V_{g}$, the maximum AC current $\left(I_{S_{\text {Max }}}\right)$ is deduced from the following expressions:

$$
\begin{gathered}
S_{g}=\sqrt{P_{g}^{2}+Q_{g}^{2}}<S_{g_{\text {Max }}} \\
S_{g_{\text {Max }}}=3 V_{g} I_{S_{\text {Max }}}
\end{gathered}
$$

where the admissible AC current in a $d q$ frame is given in a form of a circle equation (Fig. 15):

$$
i_{s_{d}}^{2}+i_{s_{q}}^{2}<I_{s_{\text {Max }}}^{2} \text {. }
$$

Then the limitation of the converted AC power can vary along with the variation of the $\mathrm{AC}$ grid voltage. It is notable that the variations of the DC grid voltage have no impact on this limitation.

\section{Maximum AC Voltage}

By neglecting the filter resistance $R_{S}$ in equations (1) and (2), and considering the steady state, we obtain:

$$
\begin{aligned}
& v_{m_{d}}=-\omega L_{s} i_{s_{q}}+v_{g_{d}} \\
& v_{m_{q}}=\omega L_{s} i_{s_{d}}+v_{g_{q}} .
\end{aligned}
$$

When the rotating $d q$ frame is synchronized with $\mathrm{AC}$ voltages, the quadrature component $v_{g_{q}}$ is equal to zero. The magnitude of the modulated voltage is expressed as:

$$
v_{m}^{2}=v_{m_{d}}^{2}+v_{m_{q}}^{2} \text {. }
$$

Then a second circle equation is obtained:

$$
i_{s_{d}}^{2}+\left(-i_{s_{q}}+\frac{v_{g_{d}}}{\omega L_{s}}\right)^{2}=\frac{v_{m}^{2}}{\left(\omega L_{s}\right)^{2}} .
$$

As the AC voltage has a maximum magnitude, $V_{m_{\text {Max }}}$, the operating point of grid currents, $i_{s_{d}}$ and $i_{s_{q}}$, must be within the circle with the radius equals to $V_{m_{\text {Max }}} /\left(\omega L_{s}\right)$.

$$
i_{s_{d}}^{2}+\left(-i_{s_{q}}+\frac{v_{g_{d}}}{X_{s}}\right)^{2}<\frac{V_{m_{M a x}}^{2}}{X_{S}^{2}}
$$

According to the equation (12), it is obvious that this radius can vary along with the variation of the DC grid voltage. Hence the admissible operating range which the converter will also change its size. 
COMPEL - The international journal for computation and mathematics in electrical and electronic engineering, Vol. 36 Iss: 1, pp. $240-257,2017$

\section{Admissible DC Current}

The DC current is limited by the thermal capability of the cable. By neglecting the switching and phase reactor losses, the limitation is then expressed as:

$$
\frac{\left|P_{g}\right|}{u_{s}}<\left|I_{l_{\text {Max }}}\right| \text {. }
$$

\section{E. Capability operating domain}

The aforementioned physical limitations with various DC grid voltages $\left(u_{s}\right)$ are drawn in Fig. 15. The allowable operation area is given by the overlapped area which satisfies all the limitations. This allowable operation area depends on the connected grid conditions and so can vary. Especially, when a DC grid voltage drop occurs, the allowable operation area can be largely reduced due to the Maximum AC Voltage (equ. 24) and the Admissible DC Current limitations (equ. 25). Therefore, the DC voltage must be maintained within a certain range, and the set points of the converter controllers $\left(p_{g}^{*}, q_{g}^{*}\right)$ must be adjusted by taking into account the new operating domain.

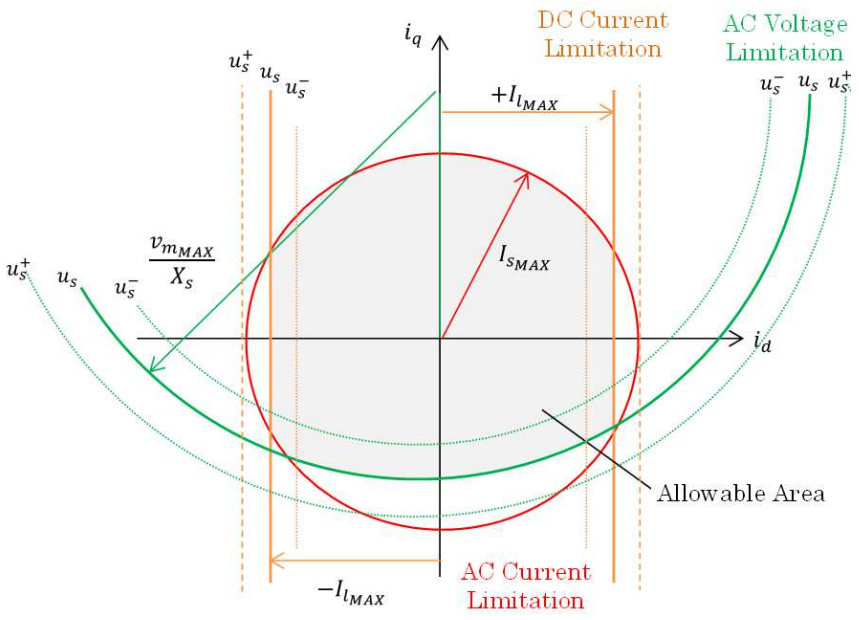

Fig. 15. Variation domain of currents for a stable operation of a VSC

\section{COMPARISON OF PRIMARY CONTROL METHODS IN A MTDC NETWORK}

To assess the modelling equations, a simulation set up has been developed with the Matlab/Simulink software. Table 5 shows the calculated control parameters. For the Master Slave method, the station VSC 1 is chosen as the Master station (fig. 1). For the Voltage Droop method, the stations VSC 1 and VSC 2 are chosen to endow for the DC voltage control. The controller parameters are calculated to obtain a $100[\mathrm{~ms}]$ response time. The tuning techniques of the primary voltage control is detailed in (Rault 2014). Table 6 shows the set points of the controllers. Power variations are caused set at $t$ $=3$ and 4 [s] at VSC 3 .

In Fig. 16 and Fig. 17, the dynamic responses of the DC grid voltage and active power controls are depicted. With the Master Slave method, only VSC 1 contributes for the voltage stabilization. In the case of the Droop voltage method, VSC 1 and 2 adjust their power output to compensate the power imbalance.
Since the same droop values are assigned, the contribution of the power given by the both stations are the same. With the Master Slave method, the DC grid voltage comes back to the nominal value in certain response time. With the Droop control case, the voltage is stabilized at lower or higher levels than the nominal value. Thus, it should be pointed out that the parameters of the droop controller must be carefully chosen taking into account the maximum power variation to cope, the required response time and the range of voltage margin.

\begin{tabular}{|c|c|c|c|c|c|}
\multicolumn{5}{|c|}{ Table 5. Control parameters } \\
\hline \multirow{4}{*}{ Station } & \multicolumn{4}{|c|}{ Method } \\
\cline { 2 - 6 } & \multicolumn{3}{|c|}{ Master/Slave } & \multicolumn{2}{c|}{ Droop } \\
\cline { 2 - 6 } & Control & $\begin{array}{c}K p \\
\text { [p.u.] }\end{array}$ & $\begin{array}{c}K i \\
\text { [p.u.] }\end{array}$ & Control & $\begin{array}{c}k \\
\text { [p.u.] }\end{array}$ \\
\hline VSC 1 & Master & 3.91 & 82.9 & Droop & 0.723 \\
\hline VSC 2 & Slave & $\begin{array}{c}\text { Not } \\
\text { used }\end{array}$ & $\begin{array}{c}\text { Not } \\
\text { used }\end{array}$ & Droop & 0.723 \\
\hline VSC 3 & Slave & $\begin{array}{c}\text { Not } \\
\text { used }\end{array}$ & $\begin{array}{c}\text { Not } \\
\text { used }\end{array}$ & $\begin{array}{c}\text { Power } \\
\text { Control }\end{array}$ & Non \\
\hline
\end{tabular}

Table 6. Set points of the stations

\begin{tabular}{|c|c|c|c|c|c|}
\hline \multirow{2}{*}{\multicolumn{2}{|c|}{ Reference }} & \multirow{2}{*}{$\mathrm{t}[\mathrm{s}]$} & \multicolumn{3}{|c|}{ Value } \\
\hline & & & $0-3.0$ & $3.0-4.0$ & $4.0-5.0$ \\
\hline \multirow{3}{*}{ VSC 1} & $P_{\text {ref }}$ & \multirow{2}{*}{ [p.u.] } & \multicolumn{3}{|c|}{0.4} \\
\hline & $Q_{\text {ref }}$ & & \multicolumn{3}{|c|}{-0.1} \\
\hline & $U_{d c r e f}$ & {$[\mathrm{kV}]$} & \multicolumn{3}{|c|}{640} \\
\hline \multirow{3}{*}{ VSC 2} & $P_{\text {ref }}$ & \multirow{2}{*}{ [p.u.] } & \multicolumn{3}{|c|}{0.1} \\
\hline & $Q_{\text {ref }}$ & & \multicolumn{3}{|c|}{-0.1} \\
\hline & $U_{d c r e f}$ & {$[\mathrm{kV}]$} & \multicolumn{3}{|c|}{640} \\
\hline \multirow{3}{*}{ VSC 3} & $P_{\text {ref }}$ & \multirow{2}{*}{ [p.u.] } & -0.5 & -0.35 & -0.75 \\
\hline & $Q_{\text {ref }}$ & & \multicolumn{3}{|c|}{-0.1} \\
\hline & $U_{\text {dcref }}$ & {$[\mathrm{kV}]$} & \multicolumn{3}{|c|}{ Non } \\
\hline
\end{tabular}

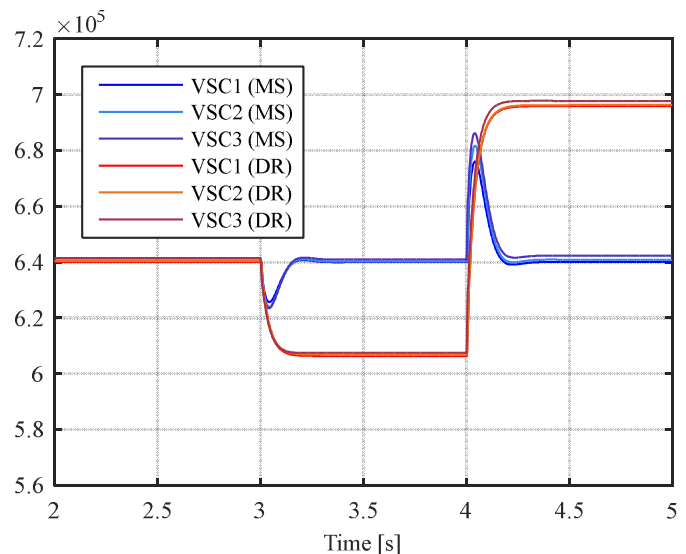

Fig. 16. Dynamic response of DC grid voltages 
COMPEL - The international journal for computation and mathematics in electrical and electronic engineering, Vol. 36 Iss: 1, pp. $240-257,2017$

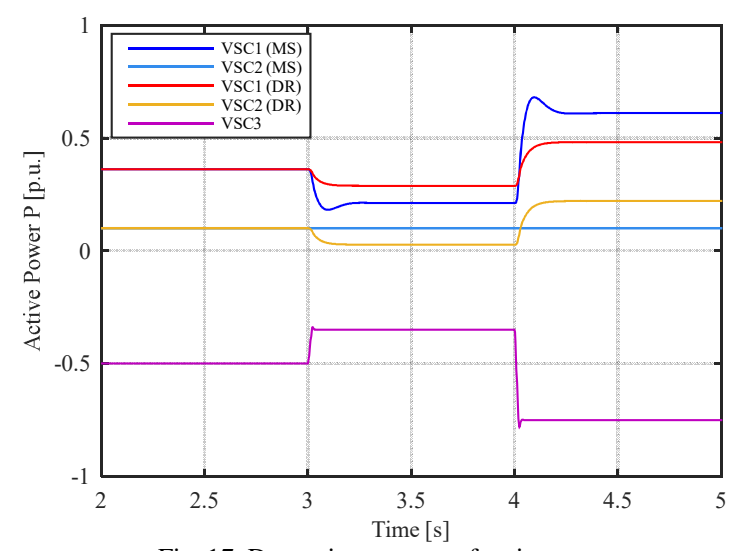

Fig. 17. Dynamic response of active powers

\section{CONCLUSIONS}

In this paper, the dynamic stability of a MTDC system has been analysed and assessed through an adequate simulation model including its control scheme. Firstly, a 2-level VSC model and its local controls were recalled. The inner control, which implements the modulation of VSC and regulation of the PCC voltage, and the outer controls, which are in charge of the output power regulation or the DC grid voltage, have been developed.

Secondly appropriate DC cable models have been developed. It was clarified that the simple $P I$ electrical circuit model does not represent the actual HVDC cable behavior. Hence, the improvement of the cable model was carried out by taking into account the mutual coupling of the cable core and the sheath. The characteristics in frequency domain are compared with the Wide Band model and the validity of the developed cable model was confirmed. Thirdly, those developed models are combined to form a MTDC grid system. In addition, main primary voltage controls were developed and embedded. The dynamic stability on the developed MTDC model was observed, and the differences in dynamics coming from the embedded primary controls were analysed.

In future works, the use of a Modular Multilevel Converter (MMC) instead of a PWM based 2-level VSC will be considered. The difference in voltage and current control can have an impact on the dynamics. It is also important for the design of MTDC network to investigate the fault ride through capability in case of the loss of one power equipment $(\mathrm{N}-1$ situation). In this case, the design of automatic reconfiguration methods taking into account the physical limitations of the MTDC grid should be concerned.

\section{REFERENCES}

Ackermann, T. and Negra, N. (2005), "Evaluation of Electrical Transmission Concepts for Large Offshore Windfarms", Proceeding of Offshore Wind Conf. and Expo. Copenhagen, pp. 1-10.

Akkari, S., Dai, J., Petit, M., Rault, P., and Guillaud, X. (2015), "Small-Signal Modelling for In-Depth Modal Analysis of an MTDC System," in Electrical Power and Energy Conference (EPEC), 2015 IEEE, pp. 233-238.
Andersen, B. et al. (2005), "VSC Transmission”, Cigré, Workgroup B4.37, TB 269.

Asplund, G. et al. (2013), "HVDC Grid Feasibility Study", Cigré, WorkGroup B4-52, TB 533.

Bacha, S., Munteanu L. and Bratcu A. L. (2014), "Power electronic converters modeling and control”, Springer, 2014, ISBN 9781447154778

Barker, C. and Whitehouse, R. (2010), "Autonomous converter control in a multi-terminal HVDC system”, International Conference on AC and DC Power Transmission, 2010, pp.1-5.

Barnes, M. and Beddard, A. (2012),'Voltage Source Converter HVDC Links - The State of the Art and Issues Going Forward", Energy Procedia, 24, pp.108-122.

Bell, K. et al. (2010), "Economic and technical criteria for designing future off-shore HVDC grids", In IEEE PES Innovative Smart Grid Technologies Conference Europe, ISGT Europe, Gothenburg, pp. 1-8.

Bouhali, O. et al. (2009), "Power sizing and control of a three-level NPC converter for grid connection of wind generator", ELECTROMOTION Journal, 16, pp.38-48.

Broutin D. and Francois B. (2000), "Influence of Medium Voltage Distribution System Models: Application to the study of the Harmonic Propagation," in Symposium on Power Electronics, Electrical Drives, Automation \& Motion: SPEEDAM, 13-16 June 2000, Ischia, Italy, CD

Davigny A., Francois B., Henneton A., Sprooten J., Robyns B. (2012), Electricity Production from Renewable Energies, Wiley, ISBN: 978-184821-390-6.

Descloux, J. (2013), "Protection contre les courts-circuits des réseaux à courant continu de forte puissance", $\mathrm{PhD}$ Thesus report, Université de Grenoble.

Dragon, J., Werner, L., and Hanson, J. (2014), "Effects of DC voltage droop characteristics on contingency behaviour of AC/DC systems," Proc. Univ. Power Eng. Conf., pp. 1-6.

European Commission (2014), "A policy framework for climate and energy in the period from 2020 to 2030", Available at: http://eurlex.europa.eu/legal-content/EN/ALL/?uri=CELEX:52014DC0015.

Gherbi, A., Francois, B. and Belkacemi, M. (2006), "Methods for power system transient stability analysis: State of the art", Canadian Journal of Electrical and Computer Engineering, Vol. 31, No 1, pp 3-13.

Gonzalez-Longatt, F.M., Roldan, J.M. and Rueda, J.L. (2013), "Impact of DC control strategies on dynamic behaviour of multi-terminal voltagesource converter-based HVDC after sudden disconnection of a converter station", IEEE POWERTECH 2013, Grenoble, pp. 1-6.

Haileselassie, T.M., Molinas, M. and Undeland, T. (2008), "Multi-Terminal VSC-HVDC System for Integration of Offshore Wind Farms and Green Electrification of Platforms in the North Sea”, In Nordic Workshop on Power and Industrial Electronics (NORPIE 2008), pp. 1-8.

Jones, P.S. and Davidson, C.C. (2013), "Calculation of power losses for MMC-based VSC HVDC stations, "15th European Conference on Power Electronics and Applications (EPE 2013), pp.1-10.

Kocar, I., Mahseredjian J., and Olivier G. (2008), "Weighting method for transient analysis of underground cables," IEEE Trans. Power Deliv., vol. 23 , no. 3, pp. 1629-1635.

Lee, S., Lee, J.H. and Cha, H. (2011) , "Grid synchronization PLL robust to frequency variation, unbalanced and distorted voltage", IEEE Energy Conversion Congress and Exposition (ECCE 2011), pp.1150-1155.

Nakajima, T. and Irokawa, S. (1999) , "A control system for HVDC transmission by voltage sourced converters", In Conference Proceedings of the 1999 IEEE Power Engineering Society Summer Meeting, Edmonton, Alta., pp. 1113-1119.

Rault P.. (2014), "Modélisation Dynamique et Commande des Réseaux à Courant Continu Multi-Terminaux Haute Tension", PhD Thesus report, Ecole Centrale de Lille.

Pinto, R.T. et al. (2011), "Comparison of direct voltage control methods of multi-terminal DC (MTDC) networks through modular dynamic models", In Proceedings of the 2011 14th European Conference on Power Electronics and Applications, pp.1-10.

Robyns, B. et al. (2002), "Equivalent Continuous Dynamic Model of Renewable Energy Systems", $7^{\text {th }}$ International Conference on Modeling and Simulation of Electric Machines", Converters and Systems: ELECTRIMACS 2002, 18-21 Aout 2002, Montreal, Canada, CD

Schifreen, C.S. and Marble, W.C. (1956), "Charging Current Limitations in Operation or High-Voltage Cable Lines", Transactions of the American 
COMPEL - The international journal for computation and mathematics in electrical and electronic engineering, Vol. 36 Iss: 1, pp. $240-257,2017$

Institute of Electrical Engineers. Part III: Power Apparatus and Systems, 75(3), pp.803-817.

Bazargan, M. Xu, L., Yao, L. and

(2009), ”DC grid management of a multi-terminal HVDC transmission system for large offshore wind farms. International Conference on Sustainable Power Generation and Supply, pp.1-7.

Zhang, L., Harnefors, L. and Nee, H.P. (2011), 'Interconnection of two very weak AC systems by VSC-HVDC links using power-synchronization control", IEEE Transactions on Power Systems, 26(1), pp.344-355.

Z.Q. Zhu, Jiabing Hu, (2013) "Electrical machines and power-electronic systems for high-power wind energy generation applications: Part II power electronics and control systems", COMPEL - The international journal for computation and mathematics in electrical and electronic engineering, Vol. 32 Iss: 1, pp.34 - 71

Wang, W. and Barnes, M. (2014), "Power flow algorithms for multi-terminal VSC-HVDC with droop control," IEEE Trans. Power Syst., vol. 29, no. 4, pp. 1721-1730 